\title{
A study on the multiple intelligence levels of Secondary school students of Government and Private schools in Secunderabad
}

\author{
T.S.Anitha, Dr.J.Vannessa, G.Sreelakshmi \\ M.Sc,M.Phil,M.Ed, PGT, Botany, Andhrapradesh Model school,Near Khammana Palli, Baireddypalli Mandal, \\ Chitoor district. Andhra Pradesh. \\ M.Sc, P.Hd, M.Ed., Principal, Andhrapradesh Model school, Kondapak(Village and Post), Medak District, \\ Andhra Pradesh. \\ M.Sc,M.Ed.,Lecturer,Srinidhi College of Education,Kushaiguda,Hyderabad.
}

\begin{abstract}
Performance of the individual as a person, citizen, as worker and as a student largely depends upon the intelligence he/she possesses. An intelligent person has the ability to adjust himself to the changing circumstances with ease, efficiency and speed. The Main purpose of this study is to know the multiple intelligence of $9^{\text {th }}$ standard students of government and private schools in Secunderabad. The respondents comprised of 240students (120 boys and 120 girls) studying in class 9.The Students were randomly selected from a Government high school and a Private school. A Multiple intelligence profiling Questionnaire was developed by Tirri \& Nokelainen to identify the student's multiple intelligence was used for collection of data. The results revealed that

- There is a significant difference between multiple intelligence levels of government school students and private school students.

- Girls have more multiple intelligence levels than the boys.

- Government school students excel in three areas i.e., logical, interpersonal and intrapersonal than the private school students.

- Boy students are good at spiritual/naturalistic intelligence.
\end{abstract}

\section{Introduction}

There is challenge in the education field regarding the variation of student progress. No two individuals are alike in the universe. If any student wants to reach his or her goals or aims he or she has to meet many challenges like cognitive ability, efficient methods of learning, concentration, memory, intelligence, learning environment and the students progress. Children differ immensely in intelligence. Intelligence refers to Capacity to learn with speed and accuracy, Capacity to solve problems and Capacity to adjust in the society.

The theory of multiple intelligence was proposed by Howard Gardner in 1983 to more accurately define the concept of intelligence and to address the question whether methods which claim to measure intelligence are truly scientific. In his conception, a child who masters multiplication easily is not necessarily more intelligent overall than a child who struggles to do so. The second child may be stronger in another kind of intelligence and therefore, may best learn the given material through different approach, may excel in a field outside of Mathematics, may even be looking at the multiplication process at a fundamentally deeper level, which can result in a seeming slowness that hide a mathematical intelligence potentiality higher than that of a child who easily memorizes the multiplication process.

For him intelligence is as follows:

a. Linguistic/Verbal intelligence (Word Smart)

b. Logical/mathematical intelligence (Reasoning Smart)

c. Spatial/visual intelligence (Picture Smart)

d. Bodily kinesthetic intelligence (Body Smart)

e. Musical intelligence (Music Smart)

f. Interpersonal intelligence (People Smart)

g. Intrapersonal intelligence

h. Spiritual/naturalistic intelligence

Multiple intelligence is needed to reason, plan, problem solving, think abstractly, comprehend complex ideas, learn quickly and learn from experience. Intelligence is not merely book learning, a narrow academic skill. But it reflects a broader and deeper capability for comprehending our surroundings.

Intelligence is perhaps, still single most effective predicator of school achievement. This is the age for development carrier choosing, carrier success, personal well being and leadership to improve student's achievement and success. Intelligence plays an important role in life and contributes to the personal, social 
development of an individual and harmonious development of the personality of an individual. Intellectual development implies progressive changes in the mental process which go on from birth to death. Intellectual development includes various aspects such as development of concepts, perception, language, memory, reasoning, thinking and imagination. Making use of these multiple intelligences can help us restructuring our class rooms into places where everyone have higher degree of success than ever imagined. It enables the learner to understand and to develop their unique way of understanding and this empowers that person with a great self esteem and enthusiasm. This theory can help each of us build upon both our strong and weak intelligences to become more whole, happy and productive human being.

Multiple intelligence is needed to reason, plan, problem solving, think abstractly, comprehend complex ideas, learn quickly and learn from experience. Intelligence is not merely book learning, a narrow academic skill. But it reflects a broader and deeper capability for comprehending our surroundings.

Intelligence is perhaps, still single most effective predicator of school achievement. This is the age for development carrier choosing, carrier success, personal well being and leadership to improve student's achievement and success.

\section{Statement Of The Problem}

A study on multiple intelligence levels of Secondary school students of Government and Private schools in Secunderabad.

\section{Need And Significance Of The Study}

In today's education Intelligence is the most important single variable which affects success in school and in life. In general terms intelligence means the manner with which an individual deals with facts and situation. Intelligence is the aggregate or the global capacity of the individual to act purposefully, to think rationally and to deal effectively with the environment.

In this technological and competitive world the performance of the individual as a person, as a citizen, as a worker and as a student largely depends upon the intelligences he possess. A child differs immensely in intelligence.

Gardner multiple intelligence theory opened new vistas in education. The theory of multiple intelligence functions for organizing and synthesizing the educational innovations that have sort to break out of the narrowly confined approach to learning. This theory opens the doors to wide variety of teaching strategies that can be easily implemented in the Class Room. Every child is endowed with unique and diverse gifts and talents, there by enriching them in the process of solving the problems. The education system should device ways and means to educate the whole child instead of doing so in a fragmented manner. This would require establishing generic connection among separate and distinct subject areas in the curriculum. It should purposively integrate in meaningful manner and illustrated through interactive activities in all content areas to take care of the diverse needs of all the students. As the content and its presentation become more interactive, students start processing the information by utilizing the active learning opportunities. Generally intelligence refers to one's own ability to accommodate him or her to the situation. But multiple intelligence refers to the ways to adopt the situation. Every human being consists of any one or more of the intelligence among the identified nine categories. And hence all are intellectuals. It is easy to both student and teacher, for teaching and learning a concept or a unit through any one of the sub type of multiple intelligence which is more appropriate for them. Hence study on Multiple Intelligence is important for providing opportunities for problem solving in both realistic and fantasy situations, giving opportunities to design products using strengths and interest as a guide, providing opportunities to the students to acquire skills and information using multiple intelligence, planning learning experiences around abstract themes and bringing the students own culture and experiences into the curriculum while expanding from this base into the other related areas.

\section{OBJECTIVE:}

To study the multiple intelligence levels of $9^{\text {th }}$ class boys and girls in Government and Private Schools of Secunderabad.

\section{HYPOTHESES OF THE STUDY}

a. There is no significant difference between mean multiple intelligence scores of students of Government and Private schools.

b. There is no significant difference between mean multiple intelligence scores of Government Boys and Government Girls.

c. There is no significant difference between mean multiple intelligence scores of Private Boys and Private Girls. 
d. There is no significant difference between mean multiple intelligence scores of Government Boys and Private Boys.

e. There is no significant difference between mean multiple intelligence scores of Government Girls and Private Girls.

f. There is significant difference in the different areas of multiple intelligence levels of Boys and Girls.

\section{DELIMITATIONS}

a. The sample is limited to 240

b. Study is conducted in urban area only

c. The researcher has taken up only two schools for the study.

d. The study is limited to ninth class only.

\section{METHODS USED}

The present study is a Descriptive survey which involves collecting the data in order to test the Hypotheses.

\section{TOOLS USED}

Multiple intelligence profiling Questionnaire was developed by Tirri \& Nokelainen to identify the students multiple intelligence. It consisted of 40 statements, each statement refers to some kind of intelligence discovery and necessary to respond all items. In the present questionnaire, multiple intelligence level considered to constitute eight different kinds of intelligences. These eight components of multiple intelligences were identified and subsequently validated by several experts. Questionnaire is a five-point likert scale, self rating questionnaire. Each statement had 5 responses. The subjects were asked to indicate their position simply by ticking $(\sqrt{ })$ in any one of the cells $\square$ with response such as Totally disagree (1), Disagree (2), Undecided (3) , Agree (4), Totally agree (5).

\section{Sample Of The Study}

Population Of The Study

The Government and private Schools located in Secunderabad city constitute the target population.

\section{SAMPLING UNITS:}

Sample 1: 60 Girls and 60 Boys of class IX of a Government school

Sample 2: 60 Girls and 60 Boys of Class IX of a Private school

SAMPLING TECHNIQUE ADOPTED

The research was conducted using random sampling method and research was survey.

\section{STATISTICAL TECHNIQUES}

- Mean

- Standard Deviation

- T-test

\section{ANALYSIS OF DATA}

TABLE-I

Mean, S.D, t-value for multiple intelligence levels of Government and Private school students.

\begin{tabular}{|l|c|c|l|}
\hline Multiple intelligence levels & Mean & Standard deviation & t-value \\
\hline Government school students & 156.6 & 11.43 & \multirow{2}{*}{4.41} \\
\hline Private school students & 138.06 & 13.74 & \multirow{2}{*}{} \\
\hline
\end{tabular}

$\mathrm{df}=118 ; \mathrm{t}$-value $=4.41$.

The table value at 0.05 level is 1.98.The obtained value $4.41>1$.98. Hence null hypothesis is accepted.

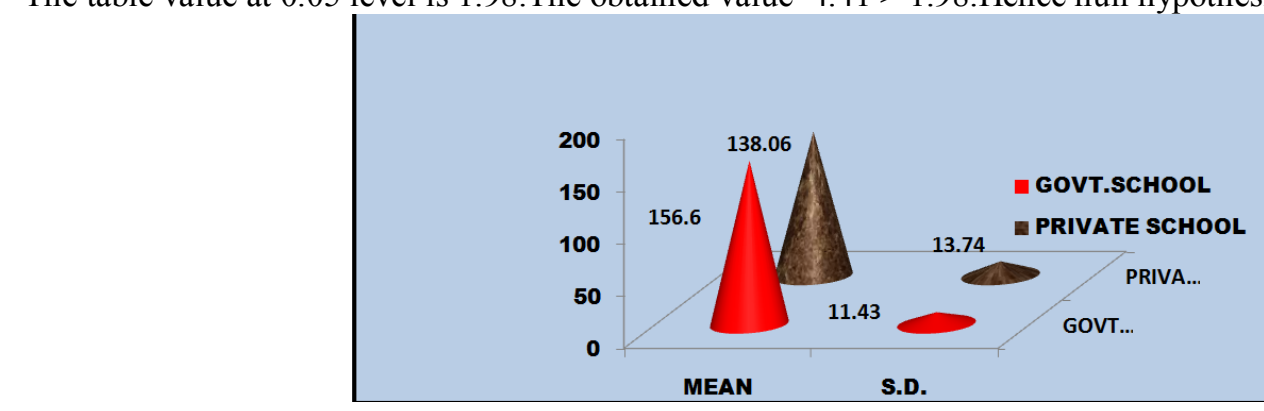


TABLE-II

Mean, S.D, t-value for multiple intelligence levels of Government school students.

\begin{tabular}{|l|c|c|c|}
\hline Multiple intelligence levels & Mean & Standard deviation & t-value \\
\hline Government school Girls & 158.6 & 10.17 & \multirow{2}{*}{0.35} \\
\hline Government school Boys & 154.66 & 12.6 & \\
\hline
\end{tabular}

$\mathrm{df}=58 ; \mathrm{t}$-value $=0.35$

The permissible value from $t$ table at 0.05 level of significance is 2.00.

$0.35<2.00$.Hence null hypothesis is accepted.

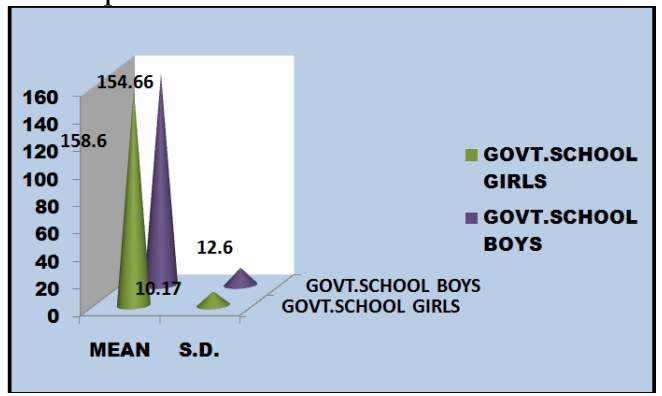

\subsubsection{TABLE-III}

Mean, S.D, t-value for multiple intelligence levels of Private school students.

\begin{tabular}{|l|c|c|l|}
\hline Multiple intelligence levels & Mean & Standard deviation & t-value \\
\hline Private school Girls & 143.8 & 13.19 & \multirow{2}{*}{0.01} \\
\hline Private school Boys & 132.26 & 12.05 & \\
\hline
\end{tabular}

$\mathrm{df}=58$; $\mathrm{t}$-value $=0.01$.

The permissible value from $t$ table at 0.05 level of significance is 2.00 .

Then, $\mathrm{t}=0.01<2.00$. Hence null hypothesis is accepted.

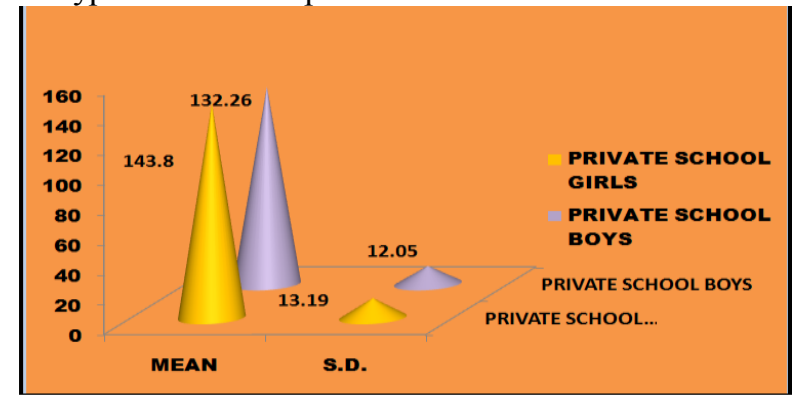

4.3.4 TABLE-IV

Mean, S.D, t-value for multiple intelligence levels of Government and Private school Girls.

\begin{tabular}{|l|c|c|c|}
\hline Multiple intelligence levels & Mean & Standard deviation & t-value \\
\hline $\begin{array}{l}\text { Government school Girls } \\
\text { Private } \\
\text { school Girls }\end{array}$ & 158.6 & 10.17 & \\
\hline
\end{tabular}

$\mathrm{df}=58 ; \mathrm{t}$-value $=0.001$

The permissible value from $t$ table at 0.05 level of significance is 2.00 .

Then, $\mathrm{t}=0.001<2.00$. Hence null hypothesis is accepted.

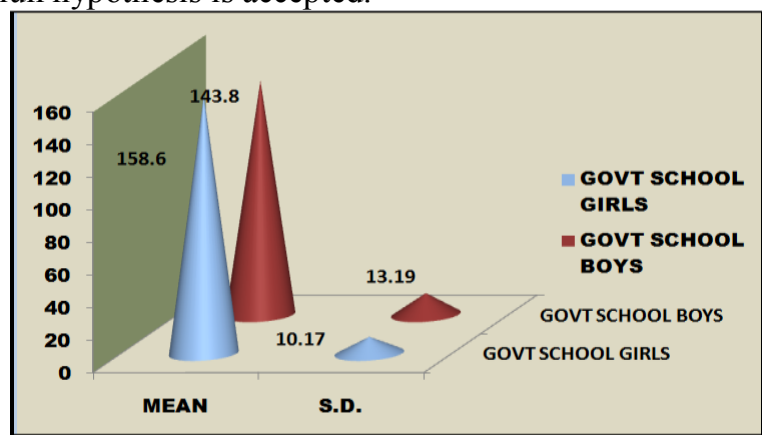


TABLE-V

Mean, S.D, t-value for multiple intelligence levels of Government and Private school Boys.

\begin{tabular}{|l|c|c|l|}
\hline Multiple intelligence levels & Mean & Standard deviation & t-value \\
\hline Government school Boys & 154.66 & 12.6 & \multirow{2}{*}{2.96} \\
\hline $\begin{array}{l}\text { Private } \\
\text { school Boys }\end{array}$ & 132.26 & 12.05 & \\
\hline
\end{tabular}

$\mathrm{df}=118 ; \mathrm{t}$-value $=2.96$

The permissible value from $t$ table at 0.05 level of significance is 1.65

Then, $\mathrm{t}=2.96>1.65$. Hence null hypothesis is rejected.

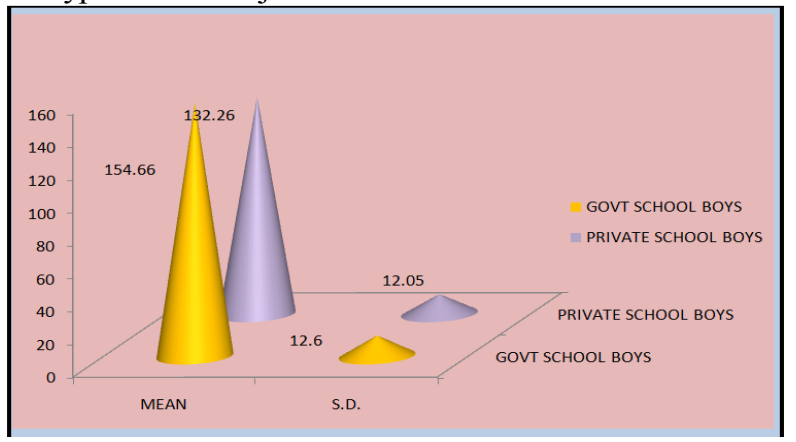

TABLE-VI

Percentages of different areas of multiple intelligence levels of Boys and Girls

\begin{tabular}{|l|c|c|c|c|c|c|c|l|}
\hline Areas & Linguistic & Logical & Musical & $\begin{array}{c}\text { Bodily- } \\
\text { kinesthetic }\end{array}$ & Spatial & $\begin{array}{c}\text { Inter } \\
\text { personal }\end{array}$ & Intra personal & Naturalistic \\
\hline Boys & $63.4 \%$ & $68.5 \%$ & $67.1 \%$ & $64.6 \%$ & $72.6 \%$ & $73.8 \%$ & $73.2 \%$ & $90.4 \%$ \\
\hline Girls & $74.1 \%$ & $78.5 \%$ & $70 \%$ & $76.4 \%$ & $69.9 \%$ & $80.8 \%$ & $81.3 \%$ & $73.9 \%$ \\
\hline
\end{tabular}

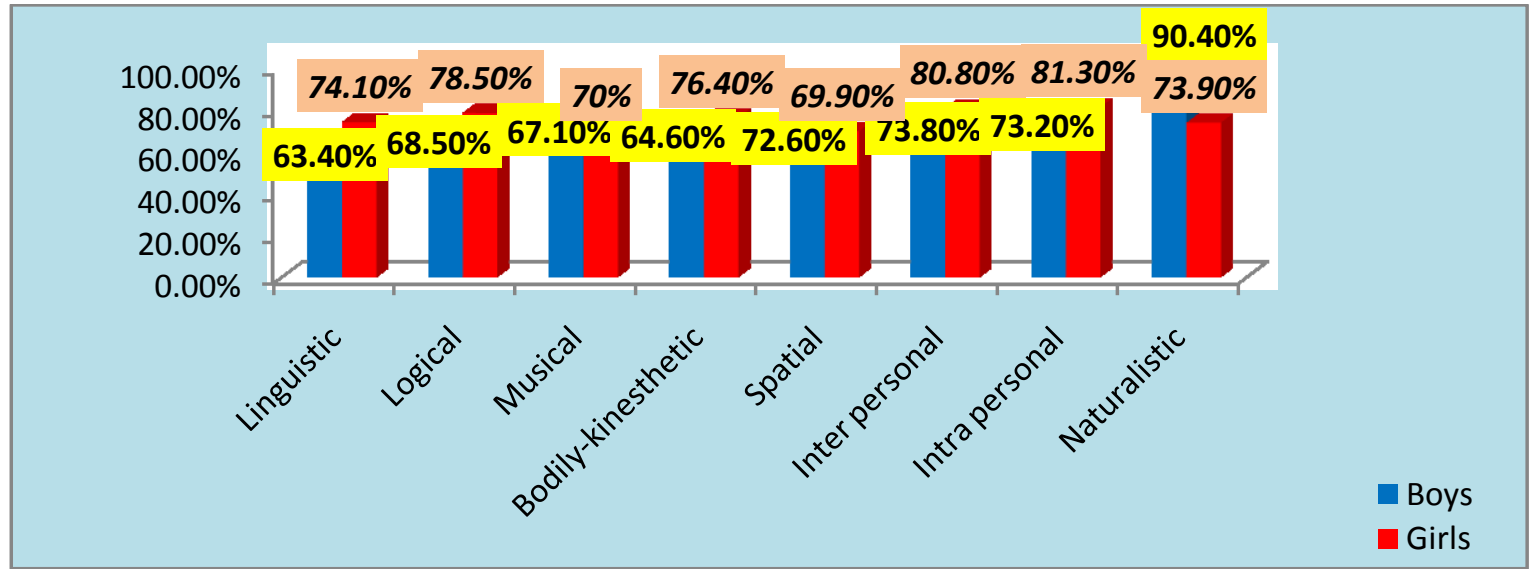

Table1:

The obtained $\mathrm{t}$ value is 4.41 and table $\mathrm{t}$ value at 0.05 level of significance is 1.98 .

As the obtained $t$ value is less than the table value, null hypothesis is retained. Hence the study reveals that there is no significant difference between mean multiple intelligence scores of students of Government and Private schools.

Table2:

The obtained $t$ value is 0.35 The table $t$ value is 2.00 at 0.05 level of significance. As the obtained t value is less than the table value, null hypothesis is retained. Hence the study reveals that there is no significant difference between mean multiple intelligence scores of Government Boys and Government Girls.

Table3: 
The obtained $t$ value is 0.01 The table $t$ value is 2.00 at 0.05 level of significance. As the obtained $t$ value is less than the table value, null hypothesis is retained. Hence the study reveals that there is no significant difference between mean multiple intelligence scores of Private Boys and Private Girls.

\section{Table4:}

The obtained $t$ value is 0.001 . The table $t$ value is 2.00 at 0.05 level of significance. As the obtained $t$ value is less than the table value, null hypothesis is retained. Hence the study reveals that there is no significant difference between mean multiple intelligence scores of Private girls and Government Girls.

\section{Table5:}

The obtained $t$ value is 2.96 . The table $t$ value is 1.65 at 0.05 level of significance. As the obtained $t$ value is more than the table value, null hypothesis is rejected. Hence the study reveals that there is significant difference between mean multiple intelligence scores of Government Boys and Private Boys.

\section{Table 6:}

Table 6 reveals that there exists difference in multiple intelligence levels of boys and girls students in all areas. Girls have more multiple intelligence levels in different areas (Linguistic, Logical, Spatial, Bodily kinesthetic, Musical, Interpersonal, Intrapersonal, Spiritual/ naturalistic intelligence), when compared to boys. But boys have more spiritual intelligence than girls.

\section{FINDINGS OF THE STUDY}

$>$ Government school students have more multiple intelligence levels than Private school students

$>$ Girls are have more multiple intelligence levels than the Boys

$>$ Girls excelled in three areas of multiple intelligence, i.e logical, interpersonal \& intra personal intelligences

$>$ Boy students are good at spiritual/ naturalistic intelligence

\section{Conclusion}

Our major motivation, when operationalizing Gardener's theory, is to provide learners and their meaningful self-reflection regarding each one's potentials. Perceptions of individual strengths are also connected to self-concept and attribution. An individual's effort is most effective when it is sustained by some urge to express himself to make to do something in a unique way. Intelligence is an umbrella term describing a property of the mind comprehending related abilities. Each person possesses one or more intelligence, to find out that intelligence in the person Gardner prepared multiple intelligence theory. There is significant difference between multiple intelligence levels of government school students and private school students. Students also differ in different areas of intelligence.

Apart from academics, there are many fields an individual can excel. Academics are a part of life, but not whole life. Every individual is has intelligence in one or the other area. Everyone should identify their inner capacities; they should develop their skills in that area.

[1]. ADAMUS, GREGORY STANELY (2000)

\section{Biblography}

[2]. "The effect of explore to multiple intelligences theory on high school student." International abstract, vol.61-07, sec-A, p.2650.

[3]. BRUCE JERRY.A, KORDINAK THOMAS.S. HARMANJ MARSHA(2008) "Current trends in assessment." Journal on Educational psychology, vol.2. No.3. p.09-13.

[4]. BAUER.H.RICHARD(2009)

[5]. "What does neuro science and cognitive psychology tells about multiple intelligence." Journal on Educational psychology, vol.2. No.3, p.26-33.

[6]. BRUKE, DOROTHY M.(1998)

[7]. "Multiple intelligence profiles to success in computer based concept mapping." International abstract, vol.59-03, sec-A, p.0891.

[8]. FISHER, ELIZABITH MOORE(1997)

[9]. “A cross case survey of research based on Howard Gardner's theory of Multiple intelligence." International abstract, vol.58-11, secA, p.4171.

[10]. GOLD ALLENE WHITE(2002)

[11]. "Knowledge and attitude of teachers towards utilization of multiple intelligences in class room practice." International abstract, DAI-A63/05, p.1688

[12]. STOCK STILL, DANIEL BREDY(1999)

[13]. "Intelligence and faith formation and the relationship between Multiple intelligence and faith formation in adolescent." International abstract, vol.60-09, sec-A, p.3408.

[14]. SULLIVAN AMIE KISTER(1999)

[15]. "The emotional intelligence scale for children (Psychological measurement), early child hood development, multiple intelligence theory." International abstract, vol.60-01, sec-A, p.0068.

[16]. STEVENS, BRENDA JANE(1996)

[17]. "Parental influence in getting children." International abstract, vol.57-05, p.1956.

[18]. SCHIRDUAN, VICTORIA MARIE(2000) 
[19]. "Elementary students with Attention Deficit Hyper Activity Disorder (ADHD) in schools using Multiple intelligence theory: Intelligences, self concept, and achievement.” International abstract, vol.61-03, sec-A, p.0891.

[20]. TEELE SUE (1994)

[21]. "The relationship of Multiple intelligence to the instructional process." International abstract, vol.55-08, sec-A, p.2270.

[22]. VEDAPRIYA GETHSI.S (2009)

[23]. "Do age and sex of school students make significant difference in their Multiple intelligence." Journal on Educational psychology Vol.2, No.3, p.34.38 